\title{
GENSTANDSINDSAMLING OG ARBEJDERKULTUR
}

\author{
Annette Vasström
}

Hvad skal vi med det ragelse? Er arbejderkulturen fin nok til at komme på museum? Kan industriens masseproducerede billige varer virkelig påberåbe sig en ret til at vere en del af kulturarven? Var det ikke bedre om denne del af den materielle kultur, der ofte er fjernt fra det vi forstair ved kvalitet, forsvinder i glemsel? Hvordan kan man onske at gemme og udstille genstande, hvis mest karakteristiske trak er at de var tonkt som erstatning for noget andet? Plastik og bakelit for horn, tre og metal, det billige plet $i$ stedet for sølv, simpelt lergods og fajance for porcelan, presset glas $i$ stedet for krystal, nylon og viscose $i$ stedet for hor og silke. Listen er uendeligt lang.

I en artikel for nylig gjorde Niels Højlund' sig til talsmand for, at vi burde kassere en stor del af de ting, der nu samler støv på museernes magasiner. Især arbejderkulturens genstandsmateriale fik et drag over nakken - var det ikke bedre, at alle disse billige varer fra dette århundrede - det masseproducerede billige skidt - faktisk gik til grunde? Hvorfor spare på det grimme, når vi knapt nok har plads til alt det smukke?

\section{TINGENES ORDEN}

Niels Højlunds tanke er ikke ny. Igennem museernes historie har kunstdebatører (Chr. Elling) ${ }^{2}$ og andre ofte gyst over de rædsler kulturhistorikerne slæbte hjem til museerne. Ligegyldige manglebrætter og spinderokke, snavset fiskergarn og udtrådte gummistøvler. Hvor var kulturen dog henne i alt det ragelse?
Når diskussionen gang på gang kan blusse op, skyldes det at problemstillingen langt fra er uinteressant. Det diskussionen drejer sig om, er genstandenes hierarki i vores omverden og $\mathrm{i}$ museumsverdenen. Tingenes orden. Det er denne tingenes orden museerne på en grad cementerer og anfægter.

Lad os derfor først se på, hvad det egentlig er, museerne gør ved tingene, når de indsamler dem og kalder dem museumsgenstande. Museumsgenstandene er en del af den materielle kulturarv, som det er museernes pligt at indsamle og varetage. I denne process foretager museerne samtidigt et valg idet nogle genstande defineres som kulturarv, mens andre forkastes. I selve registreringsprocessen omdefineres genstandene fra at være ting, der tidligere indgik i bestemte sammenhænge $i$ et hverdagsliv til at udgøre en del af en 


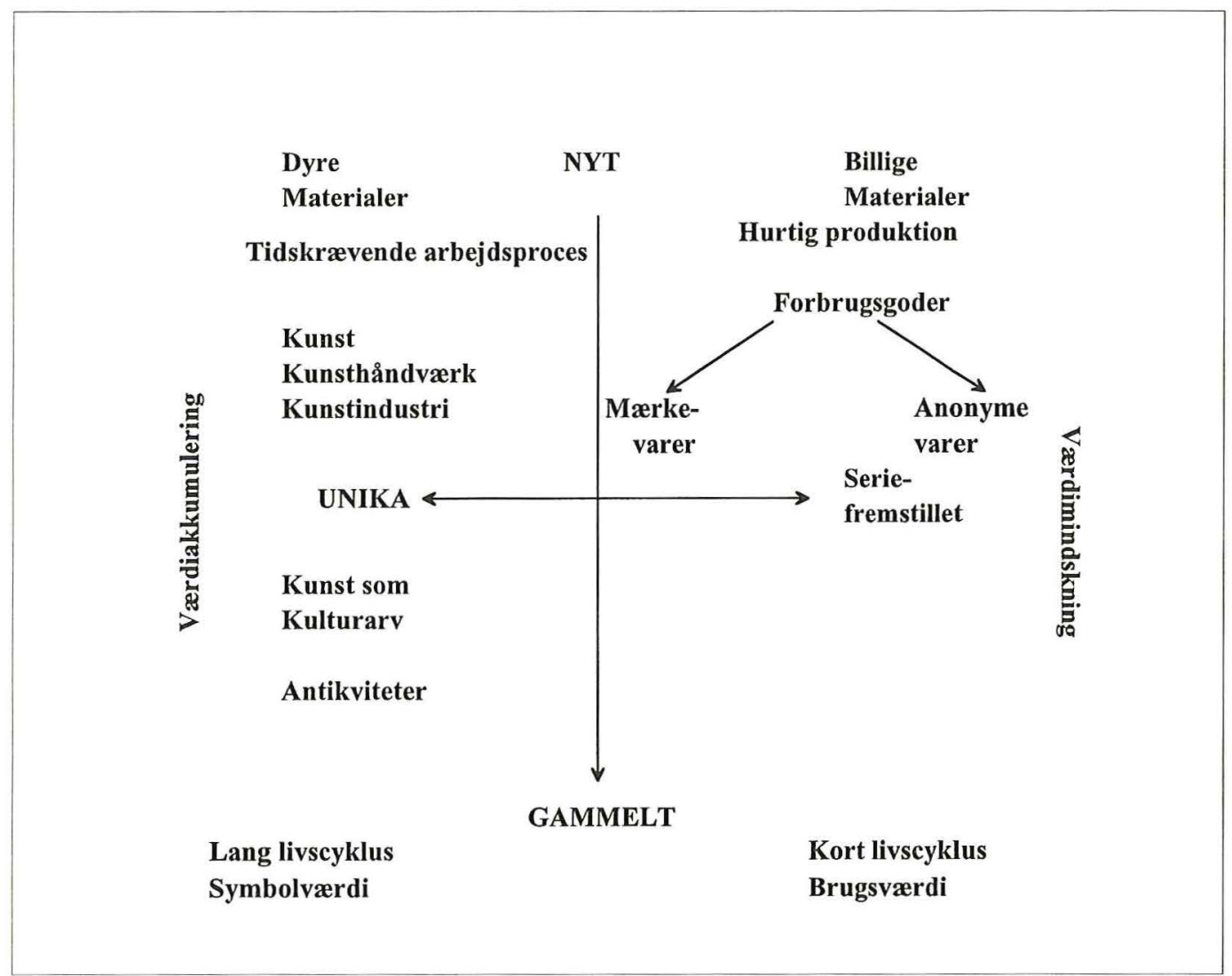

Fig. 1. Genstandenes Hierarki i markedets produktion af varer. Efter Susan Pearce, forelasning ved Museumshojskolen, november 1994.

samling på museet. På basis af genstandenes tidligere kontekst defineres de nu ind $\mathrm{i}$ en ny kontekst. Herigennem er museerne aktive i konstruktionen af den danske kulturarv på såvel det nationale som det lokale plan.

Museerne griber hermed ind i den proces, der akkumulerer værdier i samfundet. Med begreber hentet fra den franske kultursociolog Pierre Bourdieu kunne man udtrykke det således, at museernes kulturelle produktion af kulturarv griber ind $\mathrm{i}$ og influerer markedets produktion af varer. Og her intager kunstmuseerne, og tildels også de arkæologiske samlinger en anden position på markedet end de kulturhistoriske samlinger, der vedrører nyere tid.

En meget forenklet model over principperne for genstandenes hierarkisering i den industrielle verdens vareproduktion, kan give et indtryk af museernes betydning for denne produktion (se fig. 1).

Skemaet er bygget op omkring modsætningsparrene unikt og seriefremstillet/masseproduceret, gammelt og nyt. 
Industrialismen muliggjorde masseproduktion af varer i lange serier. Vareproduktionens grundlæggende vilkår blev hermed forandret. I håndværket var det håndværkerens kundskaber og materialets kostbarhed som afgjorde prisen på varen, i industriproduktionen blev tiden en meget afgørende faktor på flere områder. Meget forenklet kan man pege på, at en høj arbejdstakt med en hurtig produktionstid gjorde varen billigere end den lange produktionstid, - her spiller lønniveauet for arbejdskraften naturligtvis en stor rolle. Men tiden spiller også en rolle for omsætningen. De masseproducerede varer har en kort livscyklus sammenlignet med håndværket. De har deres maximale værdi som nye, og mindsker hastigt i værdi i takt med brug og nedslidning. Dette gxlder især for de anonyme varer, der fremstilles i store serier, mens varer, der har tilkæmpet sig et mærke der symboliserer kvalitet, som Lego eller B \& O, har en betydeligt længere levetid og nærmer sig vilkårene for håndværkets produktion.

Produktionen af unika indenfor kunst og håndværk fungerer under andre betingelser. Her anvendes ofte dyre materialer, og arbejdet er tidskrævende. Produktionstiden er lang, men det er varens livscyklus også. Kunst og kunsthåndværk produceres principielt for evigheden. Jo ældre tingene bliver, jo højere værdi får de. Her betyder tiden ikke at tingene mindsker $\mathrm{i}$ værdi, men tværtimod at de akkumulerer værdi såvel i økonomisk som symbolsk betydning.

\section{HVEM DEFINERER KULTUREN?}

Det, der sker, når museerne indsamler ting og definerer dem som museumsgenstande, er en del af hele denne proces, som også influerer på museernes forskellige positioner i det indbyrdes hierarki.

Ser vi på museerne i forhold til unika, så er museernes funktion i høj grad at øge den værdiakkumulering, som allerede er påbegyndt uden for museerne. Kunstmuseerne bekræfter kunstnernes særlige position som hævet over den materielle tingsverden. De arkæologiske samlinger rummer sjældne levn fra forhistorien og bekræfter dermed, at genstandenes alder og unikke karakter er afgørende for deres værdi.

De kulturhistoriske museer, som indsamler genstande fra nyere tid, og især museer som Arbejdermuseet, der fortrinsvis indsamler industrikulturens produkter, fungerer $i$ en anden sammenhæng. De indsamler tingene, når de er blevet tømt for værdi, og egentlig ville havne på lossepladsen eller loppemarkedet. Og nogle af disse ting løftes så ind $\mathrm{i}$ samlingerne og mærkes som museumsgenstande, d.v.s. kulturarv. Her griber de kulturhistoriske museer direkte ind $\mathrm{i}$ vareproduktionens økonomi og vender den på hovedet: En stor del af de værdiløse ting bliver værdifuld kulturarv, mens andet kasseres som ikke-kultur. De kulturløse ting kan på nyt indgå i en ny sammenhæng, hvor de gennem loppemarkedet indgår i en ny varecirkulation, - de brugte varers marked. Her vil deres værdi øges, jo ældre de bliver.

Det at indsamle de billige industriprodukter og kalde dem kulturarv er derfor en provokerende handling og en politisk handling, fordi indsamlingen udfordrer den etablerede hierarki af genstandes værdi.

I kraft af deres forskellige betydning for konstruktionen af kulturarven indtager museerne så forskellige indbyrdes positio- 
AnnetTe Vasström

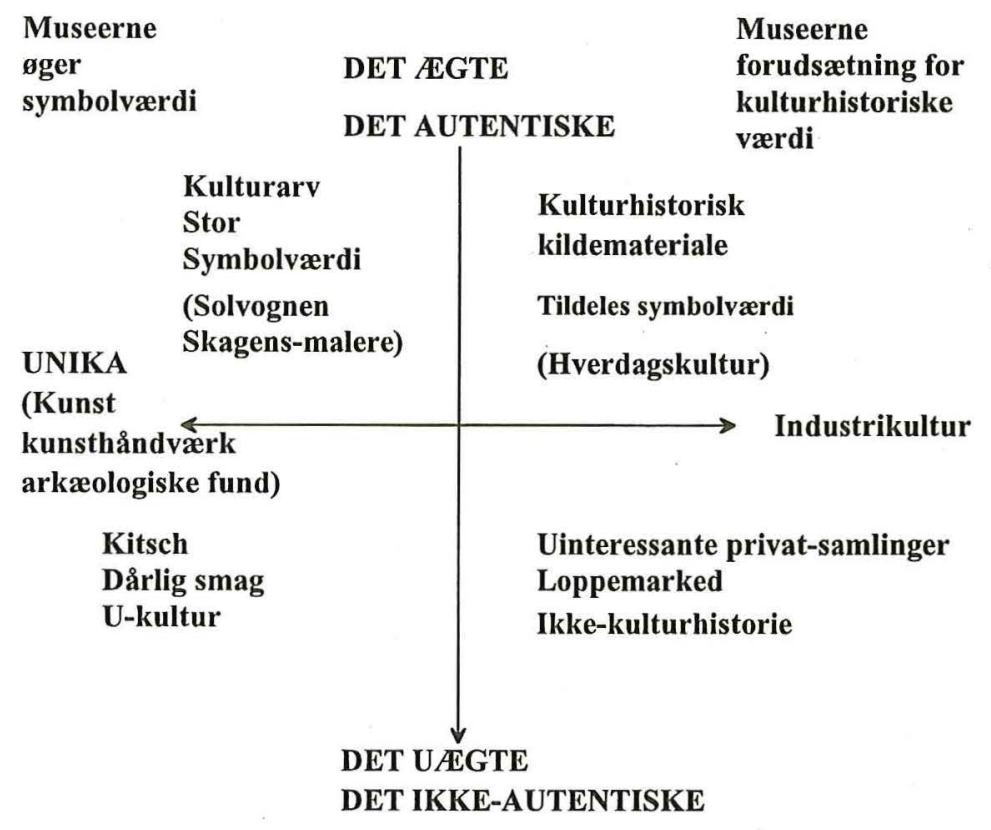

Fig. 2. Genstandenes Hierarki i produktionen af kultur(arv). Efter Susan Pearce, forelesning ved Museumshojskolen, november 1994.

ner $\mathrm{i}$ et hierarki. Kunstmuseerne rangerer højere end de kulturhistoriske museer, de arkæologiske samlinger højere end nyere tid. Og endelig spiller den rumslige faktor en stor rolle for museernes indbyrdes position. Nationalmuseet, der rummer de samlinger som legitimerer Danmark som en nationalstat, indtager en dominerende position i hierarkiet i relation til f.eks. lokalmuseerne, der kun forvalter en lokal del af kulturarven, eller til Arbejdermuseet, der kun beskæftiger sig med en bestemt socialgruppes historie.

\section{HVORFOR ET ARBEJDERMUSEUM?}

$\mathrm{Nu}$ er teoretiske analyser af museernes position og praksis én ting, - men kan teorierne legitimerer det vi gør? At vi indsamler slidte og brugte ting uden egentlige «værdier»?

Ville der egentlig ske spor ved, at der ikke eksisterede et Arbejdermuseum? Hvilken forskel gør museet, når det gælder om at dokumentere, forske og formidle viden om arbejderkulturen?

Tankeeksperimentet er ikke vanskeligt, 
idet Arbejdermuseet ikke eksisterede for 12 år siden. Ser vi derfor bort fra de genstande, som museet nu har indsamlet, hvad ville der så være for kildemateriale at bygge på, når historien om arbejderkulturen og om arbejderfamiliernes hverdag skal fortælles?

Arbejderbevægelsens Bibliotek og Arkiv var indtil museets oprettelse i 1982 den eneste institution, som varetog arbejderbevægelsens historie og kultur. Udover arkivalierne rummer arkivet også en stor samling af faner. $\mathrm{Og}$ fanerne fortæller historie. De stammer fra partiforeninger, fra fagforeninger, fra klubber på arbejdspladserne, fra sangforeninger og fra en række af den brede vifte af kulturelle institutioner, som arbejderbevægelsen var med til at grundlægge. Fanerne er ikke billigt juks, men tværtimod lavet af dyre materialer med motiver broderet i silke eller malet direkte på stoffet. Hver fane er unik.

Som en samling fortæller fanerne historien om en befolkningsgruppe, som på meget få årtier formåede at samle sig til en slagkraftig folkelig bevægelse, der omfattede et meget bredt udvalg af den danske befolkning.Med fanerne som symbol lykkedes det at opdrage og disciplinere en meget stor del af befolkningen til at kende og acceptere de demokratiske spilleregler. Man lærte at gøre sin pligt, og kræve sin ret, inden for fastlagte rammer.

Hver for sig fortæller fanerne også historie. Om faglig stolthed hos de faglærte arbejdere, og om fællesskabets store betydning for de ufaglærtes mulighed for at få bedre arbejds- og levevilkår. Gør din pligt og kræv din ret er ofte kampråbet på smedenes selvbevidste faner, mens landarbejdere og pakhusfolket mere dæmpet betoner at: samlede er vi en magt.
Men rummer fanerne og de bugnende vores viden om arbejderbevægelsen og arbejderkulturen være dækket ind af dette kildemateriale? Hvad er det Arbejdermuseets samlinger af genstande kan bidrage med?

\section{SMEDEN OG HAVNEARBEJDEREN}

Lad os se på fanerne en gang til. Som jeg næunte, så er smedefaget et fag præget af stor faglig stolthed og indtager også en stærk position på arbejdsmarkedet $\mathrm{i}$ jævnførelse med andre faggrupper. Igennem generationer har de opfattet sig selv som spydspidsen i den danske fagbevægelse, de var først med udpege tillidsmænd og danne lokale værkstedklubber som kunne stille krav overfor arbejdsgiverne, de var først med at stille krav til lærlingeuddannelsen, og den store smedekonflikt i 1897, der sluttede med en sejr til smedene, pegede frem mod de vilkår man enedes om i septemberforliget to år senere, den fælles grundlov for hele arbejdsmarkedet.

Men hvorfor stod - og står - smedene så stærkt i fagbevægelsen? har de igennem generationer haft dygtige forhandlere? Eller ligger årsagen til deres styrke et andet sted, i betingelser og vilkår for produktionen?

På de fleste arbejdspladser $\mathrm{i}$ industrien er smede og maskinarbejdernes arbejdsopgaver meget centrale for produktionen. Selv om produktionen er videnskabeliggjort og maskinerne har overtaget en stor del af arbejdet i dag, så er smede og maskinarbejderne også i dag placeret i nøglepositionerne i produktionen. $\mathrm{Og}$ sådan har det altid været. Det er på arbejdspladsen, i selve produktionen sme- 
52 dene har hentet deres styrke til at stille krav. Deres arbejde har ofte været meget selvstændigt, og de har tilegnet sig kvalifikationer som gjorde, at de ikke uden videre kunne udskiftes med anden arbejdskraft. Denne position som specialister har de forstået at drage nytte af. Det er fristende at indskyde, at det sidste netop indgåede forlig mellem arbejdsgivere og Metal peger på, at det for første gang i 100 år er lykkedes at bryde arbejdsgivernes monopol på at lede og fordele arbejdet, en stor del af denne ret ligger nu hos den lokale tillidsmand.

Fanerne fortæller os om resultatet, de selvbevidste smede, men de fortæller ikke om forudsætningerne. De må hentes hos smedene selv. Gennem interviews eller nedskrevne erindringer om vilkårene $\mathrm{i}$ arbejdet og gennem den materielle virkelighed, de var omgivet af. Derfor var det med megen begejstring Arbejdermuseet for et par måneder siden kunne takke ja til en stor gave fra havnevæsenet: den sidste fungerende skibsmedje i Københavns Havn.

Museet har fået alt fra arbejdspladsen: lufthammeren, essen, ambolten, arbejdsborde, smedetænger, smedeplan, skabe til arbejdstøj, drejebænk, slibemaskiner m.m. Vi har slæbt ankerkæder og øjebolte hjem og desuden fået mange oplysninger om navne og traditioner knyttet til værktøjerne, hvoraf nogle måske ikke er helt velegnede til offentliggørelse. Først og fremmest har vi fàet en klump hjem af den materielle virkelighed, som har været en del af grundlaget for smedenes fagstolte traditioner og selvopfattelse. Og ikke kun for smedene. Fagstoltheden er et meget væsentligt element i den kulturelle kapital, arbejderbevægelsen har søgt at opbygge, som et modsvar til det etablerede samfunds kulturelle kapital, hvor erfaringer fra arbejdslivet bestemt ikke har været en del af indholdet.

Men arbejderbevægelsen og arbejderkulturen er ikke kun historien om fagstolte arbejdere. Mange andre grupper har været aktive $\mathrm{i}$ arbejdet med at konstituere arbejderbevægelsen som en slagkraftig organisation i samfundet.

En af de grupper, som ofte har været i opposition til smedenes politik er SiD'erne, den brogede samling af arbejdsmænd og specialarbejdere, der varetager en lang række meget forskellige arbejdsopgaver, under arbejdsbetingelser, der adskiller sig markant fra smedenes. Havnearbejderne var tidligere en meget stor gruppe indenfor arbejdsmandsområdet. Som løsarbejdere havde de vilkår, der var meget anderledes end håndværkernes, og de var derfor også ofte på kant med eller i direkte opposition til den øvrige arbejderbevægelse. Havnearbejderne har igangsat nogle af de voldsommeste konflikter i Danmark, så voldsomme at den borgerlige presse sammenlignede dem med revolutionstilstande. Havnearbejdets karakter af løsarbejde har nok tiltrukket en særlig type af mennesker. I den borgerlige presse blev de beskrevet som udskud, et fordrukkent, udisciplineret pak, som ingen anstændige mennesker behøvede at bekymre sig om. I arbejdsmarkedets aftaler om arbejdsvilkår og sikkerhed udgjorde de igennem decennier en fast parantes, idet loven om arbejderbeskyttelse ikke gjaldt for havne- og pakhusarbejdere.

Havde den borgerlige presse ret? Var havnearbejderne selv skyld i deres dårlige rygte og svage position? Arbejdermuseet lavede i 1989 en udstilling om arbejdet i havnen, og kom i den forbindelse meget tæt på havnearbejdernes vilkår. I 1987 for- 
svandt løsarbejdet i Københavns Havn, men indtil da var havnearbejderne løsarbejdere. Det indebar, at de 2-3 gange om dagen skulle stille til mønstring for at få tildelt forefaldende arbejde $\mathrm{i}$ havnen. Var man heldig og havde fået foden indenfor i et godt sjak med en stærk lugemand, som var dygtig til at forhandle med stevedoren, så kunne man regne med nogenlunde sikkert arbejde i længere perioder og en rimelig arbejdsløn. Men man kunne også være uheldig. For at fà arbejde var havnearbejderne nødt til at opholde sig på havnens område fra tidlig morgen til hen på aftenen, $\mathrm{i}$ venten på at blive mønstret. Blandt havnearbejderne selv er arbejdet omgærdet af en del romantik. Man er den frie fugl, der kan tage sig en fridag når som helst, og sige nej til det beskidte arbejde. Men virkeligheden var en anden. Den bestod af lange ventetider $\mathrm{i}$ havnene og ofte meget hårdt arbejde, med risiko for helbredet. Asbesten blev skovlet op i løsvægt fra skibene, kobraen var tung at arbejde med og fuld af mider, kul og kønrøg satte sig i porerne og kunne ikke vaskes væk, og sodaen sved støvlerne af fødderne. Til hjælp med arbejdet havde havnearbejderen først og fremmest sig selv og de øvrige medlemmer af sjakket. Arbejdet krævede ikke blot fysisk styrke men også teknik, og denne teknik måtte læres af de ældre i sjakket. Og så var der de totalt uundværlige huks, arbejdskroge som kunne hugges ind $\mathrm{i}$ kasser og sække og dermed lette arbejdet. Huksen var havnearbejderens eget værktøj, fremstillet hos en lokal smed.

I København fik man de bedste fra en cykelsmed med værksted i nærheden af frihavnen. De såkaldte elefanthuks. Man kunne også være heldig at finde huks i lasten som havnearbejderne $\mathrm{i}$ andre havne havde glemt. Filipinerhuks var eftertragtede fordi de var gode til at stuve bomuldsballerne med.

I dag er den gamle havnearbejderkultur næsten forsvundet. En ny generation har taget over, med walkie-talkie kører de rundt i store containertrucks (skræverne) og to mand kan nu udføre det samme arbejde på 4 timer som tidligere krævede 12 mands arbejde i 2 dage. En periode i havnenes historie er forbi, men på Arbejdermuseet har vi bevaret erindringerne om arbejdet, de mange fortællinger og øgenavne, som trivedes i miljøet og endelig en mindre samling af havnearbejdernes huks som materielle vidnesbyrd om dette specielle arbejde. Dette materiale er vigtigt for at forstå brudflader og konflikter i arbejderbevægelsens historie. Havnearbejderens arbejdserfaringer er meget forskellige fra smedenes, og her ligger en af forklaringerne på, at nok bør arbejderbevægelsen principielt stå samlet bag krav og beslutninger, men reelt er det uhyre vanskeligt, fordi erfaringerne fra hverdagens problemer kan være så uhyre forskellige.

De genstande vi har korrigerer det officielle billede af arbejderbevægelsen, og herfra kan der hentes viden til en forståelse af konflikter og stridigheder, som giver problemer den dag i dag.

\section{HANDVARKTØJER, “FUSK» M.M.}

Havnesmedjen og huksene er på Arbejdermuseet indgået $\mathrm{i}$ den samme samling af genstande, gruppen F 9 b, som rummer genstande fra de enkelte håndværks- og industrifag. Her er godt $1 / 5$ del af museets samlinger registreret.

Gruppen spænder vidt fra håndværkernes værktøjer, svendeprøver og svendebre- 
54 ve til arbejdsmændenes ydmyge redskaber som huksen, kosten og spaden. Museet har oprettet en særlig undergruppe i denne samling, som rummer alt "fusket». Det er genstande som i deres funktion hører hjemme $i$ andre kategorier, f.eks. husholdningsinventar som ovne, havelygter, havegrill, havelåger, antenner m.m. Tingene er registreret $\mathrm{i}$ denne undergruppe, fordi vi kender historien bag dem. De er lavet af arbejderne selv, oftest er det de faglærte som fusker, på arbejdspladsen, i arbejdstiden og af arbejdspladsens materialer. Det at «fuske» er en accepteret sort/grå økonomi på de fleste arbejdspladser. Her får dygtige håndværkere afløb for den viden, de langt fra altid kan bruge i selve produktionen, og internt på arbejdspladsen giver det mulighed for at skaffe en række specialvarer af høj kvalitet, som kun få ville have råd til at købe på det åbne marked. Det er især på større virksomheder, der fuskes, fordi der her er ressourcer nok til at produktionen kan køre, selv om der går tid fra til "fusk-arbejdet». Her er alle integreret i "fuskeriet»: ingeniøren kan lave udkast til arbejdstegninger som går videre til smeden og maskinarbejderen; også andre grupper kan kobles ind som elektrikeren eller maleren. Bliver produktet vellykket kan der udvikle sig hele produktionsserier indenfor fuskeriet.

Hele genstandsgruppen - hvadenten det drejer sig om værktøjerne eller "fusket" har et præg af at være godt «kram», gedigne materialer, der har fàet en omhyggelig forarbejdning. Det er genstande som har været genstand for håndværkerens stolthed, som har været en del af en faglig identitet. Det er denne faglige stolthed som også dannede basis for organiseringen af arbejderne i stærke fagforeninger, som tidligere end i noget andet land opnår at blive anerkendt som forhandlingsberettige partnere. Septemberforliget fra 1889 er verdens æeldste grundlov for regulering af arbejdsmarkedet.

En vigtig side af arbejdernes hverdagsliv er imidlertid meget dårligt repræsenteret i samlingerne, - det gælder maskiner og andet inventar fra større arbejdspladser. Årsagen ligger i selve arbejderkulturens vilkår. Produktionsmidlerne, som maskinerne er en del af, tilhører ikke arbejderne og de har ingen rådighed over dem. De repræsenterer ofte store værdier, som ikke uden videre overlades til museerne. Industrien har desuden sit eget museum, Danmarks tekniske Museum, der indsamler maskinerne som indicier for bestemte typer af tekniske løsninger på problemer. De finder kun sjældent vej til Arbejdermuseet.

\section{FAMILIEN SØRENSEN}

Lad os gå tilbage til udgangspunktet, om Arbejdermuseets samlinger kan bidrage med en viden, der ellers ikke havde været tilgængelig. For arbejdslivets vedkommende synes det klart, at uden en genstandsindsamling ville megen tavs viden være gået tabt. Den viden om arbejdsprocesser som arbejderne sjældent læste sig til men erfarede igennem selve arbejdet.

Men også på et andet område bliver genstandsindsamlingen af betydning. Det helt fundamentale træk ved arbejderfamiliernes levevilkår var - og er - den adskillelse der er mellem arbejdslivet og den frie tid. For en stor gruppe af arbejderfamilier gælder det at den frie tid og familielivet har spillet en langt større rolle end arbejdslivet og organisationerne. Den del af hver- 
dagen findes ikke beskrevet $\mathrm{i}$ organisationernes arkivalier eller $\mathrm{i}$ andre officielle dokumenter. De vigtigste kilder til hverdagslivets historie er menneskers egne erindringer om dette liv, og så de genstande, den materielle virkelighed, som har været en del af dette liv. For arbejderfamilierne var hjemmet et område, hvor de principielt var herrer i eget hus, her var et domæne, de havde en vis kontrol over i modsætning til arbejdspladsen.

I begyndelsen af 1990 blev museet spurgt om vi var interesserede $\mathrm{i}$ at overtage en komplet lejlighed, som havde stået praktisk taget urørt siden 1915. Lejligheden havde tilhørt en arbejdsmand og hans familie, og familiens næstyngste, den nu 92-årige Yrsa, skulle flytte på plejehjem.

Historien om Yrsas lejlighed viste sig at være en historie om en helt almindelig arbejderfamilie, der engang $i$ forrige århundrede flyttede fra landet ind til byen for at få bedre muligheder. Familien bestod af brænderiarbejder P. M. Sørensen, hans kone og de 8 børn, de efterhånden skaffede sig. I 1915 flyttede de ind i en lejlighed på Gl. Kalkbrænderivej på Østerbro og her blev de boende. Da forældrene døde, overtog et par af børnene lejligheden. Der blev imidlertid ikke ændret på møbleringen eller på lejlighedens udstyr. Det, der var godt nok til forældrene, var også godt nok til børnene. Her boede så søster Karen, som var "tissekone» på toiletterne på Hovedbanegården, bror Karl som var havnearbejder, kullemper, og tilsidst lillesøster Yrsa, der bl.a. havde arbejde på Galle \& Jessens chokoladefabrik, hvor hun pakkede chokolade-frøer. Historien om familien Sørensen, som Arbejdermuseet nu har bygget en hel udstilling op omkring, er også historien om tusindvis af arbejderfamilier, der ikke satte sig andet eftermæle i historien end netop det, at de var til og levede et stilfærdigt hverdagsliv. $\mathrm{Nu}$ er lejligheden bevaret for eftertiden som en dokumentation af tusindvis af arbejderfamiliers levevilkår, unik i al sin almindelighed. Netop dette miljø kan være så vanskeligt at dokumentere, fordi genstandene herfra som regel er forsvundet - slidt op eller kasseret.

Yrsas lejlighed og alle genstande hører til den absolut største genstandsgruppe i museets samlinger, J 2 og J 3, som omfatter indbo og husgeråd. Det er her vi finder mange af de billige materialer plastik, og plet. De billige materialer og den billige fremstilling gjorde det muligt for arbejderne at erhverve sig forbrugsgoder, som tidligere var forbeholdt de mere velhavende.

Men vi finder også genstande i den modsatte ende af skalaen. Især møblerne kan være lavet af gode materialer og kan have fået en omhyggelig forarbejdning. I arbejderfamiliernes bestræbelser for at blive accepterede som fuldgyldige medborgere i samfundet indgik også en stræben efter det respektable. At kunne dokumentere man var en fuldgyldig borger, der kunne svare enhver sit, og ikke lå nogen til last. Erindringen om den gang man mistede sin stemmeret, fordi man fik hjælp fra det offentlige, ligger stadigvæk dybt forankret i den ældre arbejdergeneration. Det, at kunne præsentere sig selv og sin familie som økonomisk velfunderede, har haft betydning for den måde, man møblerede sit hjem på og den måde man klædte sig på. Det er det, de solide, gedigne møbler skal give signaler om. 
HVEM INDSAMLER TING TIL MUSEERNE

Museumssektoren er en branche i hastig vækst, ikke kun i Danmark, men overalt i Europa. Væksten er så voldsom at museumsfolkene selv knapt nok kan følge med. Men har vi ikke museer nok? Behøver vi indsamle alt, gemme på alt? I debatten om museerne og kulturarven lyder argumenterne ofte, som om det var museumsfolkene, der med en umættelig begærlighed $ø$ nskede at oprette og drive et stadigt stigende antal museer. Men hvem er egentlig drivkræfterne bag oprettelsen af museerne?

I forrige århundrede blev museumsgenstandene fra nyere tid indsamlet takket være ihærdige museumsfolks berejsninger af landet, for at opstøve resterne af den gamle, traditionelle bondekultur.

I dag er situationen snarere den modsatte. På Arbejdermuseet - og på mange andre kulturhistoriske museer - ligner indsamlingssituationen snarere en belejring end en berejsning.

Omkring $80 \%$ af de genstande, som findes i museets samlinger, er indkommet ved, at folk af sig selv har henvendt sig, fordi de mente, museet havde interesse i at bevare de genstande, de tilbød. Og i tilgift får vi ofte bemærkninger om, at giverne føler, det netop er her, tingene hører hjemme. Eller som en af vores første givere Lillian Engelhardt Pedersen, udtrykte det : Altså Egon, (som ikke ville med ind på det nyåbnede Arbejdermuseum) du er nødt til at komme med. Det her er jo vores museum!!

På Arbejdermuseet findes der 2 hovedgrupper af «brugere». Der er en vi-gruppe, af lønarbejderne, arbejderfamilierne - som selv er bærere af den kultur, museet fortæl- ler om, og så er der en stor gruppe af "de andre», de udenforstånde, der har rod i en anden kultur, men som med stor fornøjelse besøger udstillingerne. Denne anden kultur kan enten være dansk eller udenlandsk, idet museet besøges af et meget stort antal indvandrere og flygtninge. Hvor gruppen af «de andre» trods alt forbliver publikum, betragterne, så er gruppen af "os selv", arbejderfamilierne, en forudsætning for museets eksistens. Det er fra denne gruppe, museet henter sin viden om arbejderkulturen $\mathrm{i}$ dens mange forskellige variationer, og det er dem, der kontakter os for at aflevere genstande, som fortæller om deres familiers hverdagsliv $i$ arbejde og fritid.

Men ville de komme med tingene, hvis ikke de kunne genkende sig selv i udstillingerne? Formidlingen gennem genstandene, de historier museet aflokker tingene, har sammenhæng med de ting, man får tilbudt. Det er derfor svært at adskille diskussionen om museernes indsamlingspolitik fra formidlingen, for ville vi få tilbudt de ting vi faktisk får tilbudt hver eneste dag, hvis ikke giverne kunne genkende sig selv i udstillingerne, ikke fandt at de sammenhænge museet konstruerede med hjælp af genstandene modsvarede en virkelighed, som var genkendelig?

\section{HVEM ER GIVERNE?}

Arbejdermuseet opbygger sine samlinger i en tæt dialog med brugerne, giverne. Men ved vi, hvem de er?

Vi kan for det første se, at museet apellerer til hele landet og ikke kun til Københavns-området, selv om tyngdepunktet naturligtvis ligger her. Den geografiske fordeling viser også, at det ofte er efter- 


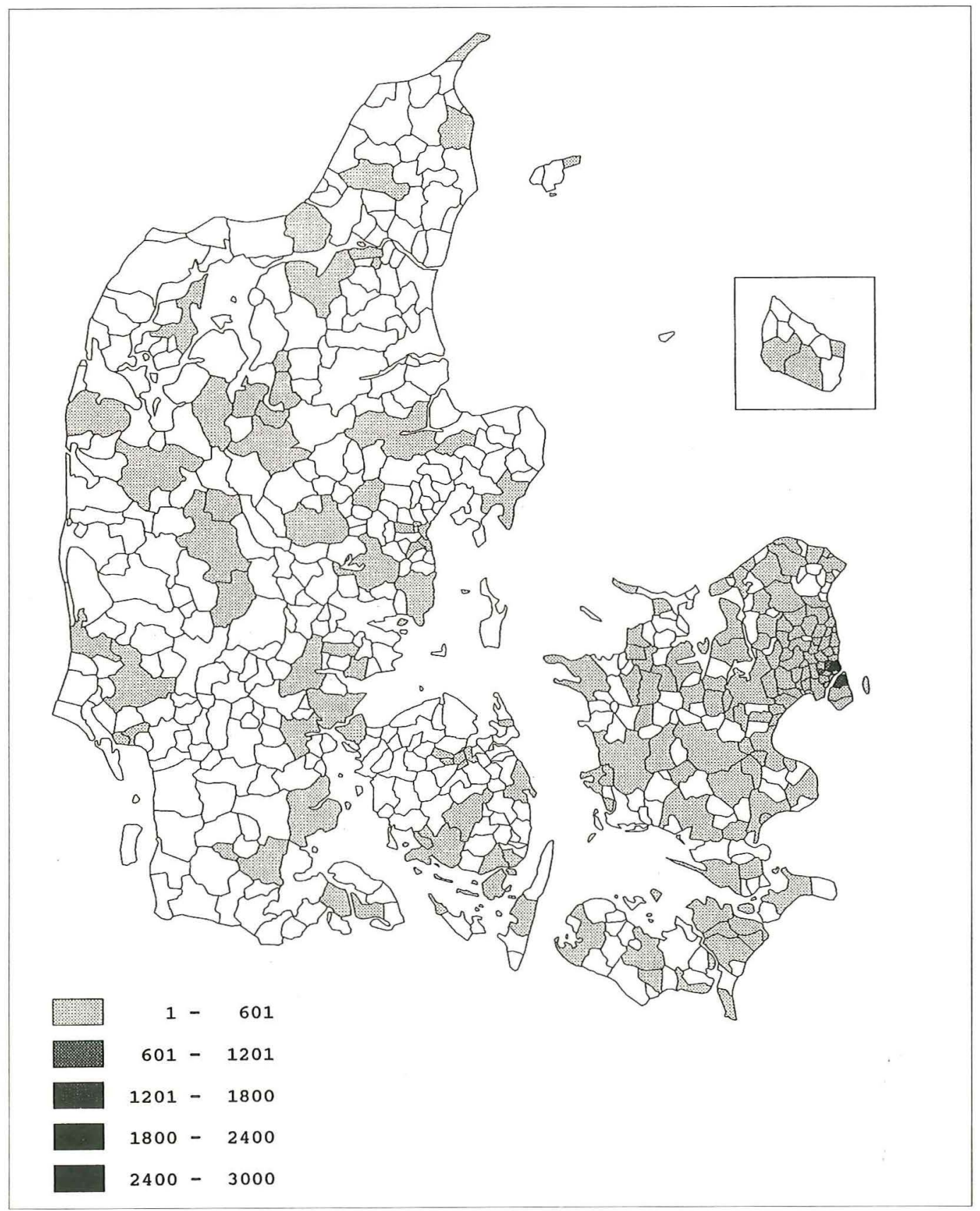

Fig. 3. Genstande ved Arbejdermuseet fordelt efter brugssted. 
ANNETTE VASSTRÖM

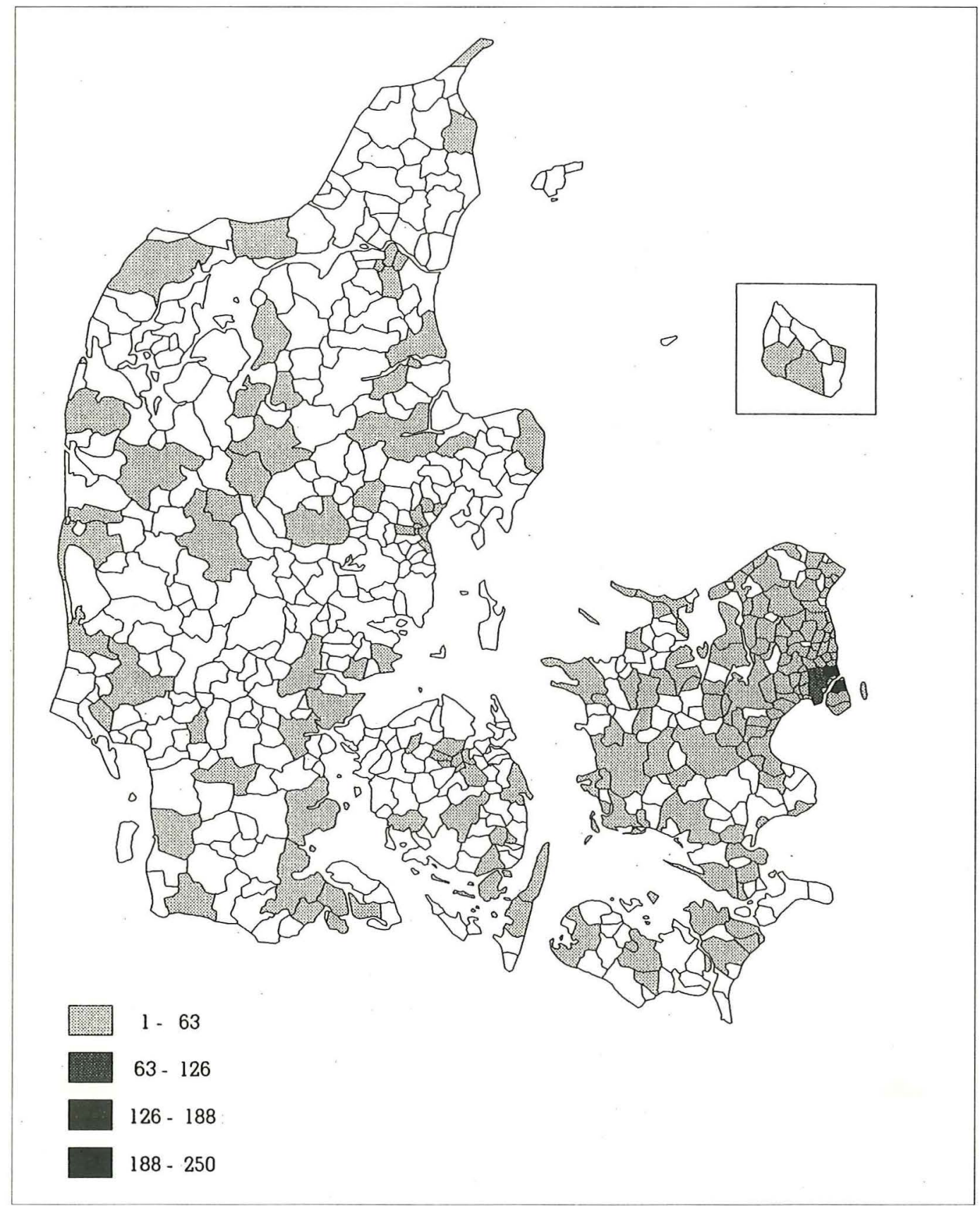

Fig. 4. Givere til Arbejdermuseet fordelt efter postnummer. 
kommerne af dem, der engang har brugt tingene, som bringer dem ind på museet. Dette er især tydeligt for Københavnsområdets vedkommende. Her er en stor del af genstandene brugt inde i den gamle industriby, indenfor kommunegrænsen, mens giverne bor i omegnskommunerne. Kortet antyder også den sociale deling af byen, med tyngdepunktet i kommunerne på vestegnen.

Hovedparten af giverne er privatpersoner, selvom organisationerne også har bidraget en del med genstande fra fagforeningernes og klubbernes faglige virksomhed. Der er ingen væsentlig forskel på kønnene med hensyn til at donére ting til museet, dog kan vi se en overvægt af mænd blandt giverne, som har foræret genstande med relation til arbejdslivet, mens kvinderne er talstærke, når det drejer sig om inventar og tøj.

Giverne kan være brugere, d.v.s. dem, der har brugt tingene, men oftere er det efterkommere i 2. eller 3. generation. Når de tilbyder ting til museet, er det, fordi de allerede, før museet er blevet involveret, har tildelt eller erkendt tingenes symbolske værdi. Det er ikke bare noget, man sådan kan smide væk, det er vigtigt, at andre kan se, man har levet sådan, er en hyppig kommentar fra giverne. Men den udvælgelse var aldrig sket, hvis ikke de havde vidst, der var et sted, som delte deres værdisætning af tingene. Museet er derfor $\mathrm{i}$ en konstant dialog med giverne om, hvad det er, der er bevaringsværdigt. Det er langt fra altid museet selv, som opsøger og udvælger og definerer kulturarven, det kan kun ske i en dialog med giverne.
HVORFOR INDSAMLER
Lad os gå tilbage til udgangspunktet og besvare spørgsmålet om, hvorfor museer indsamler genstande. Svaret forekommer enkelt: Museerne indsamler genstande, fordi de ofte er den eneste kilde til viden om almindelige menneskers dagligliv. Vi har set, hvorledes megen viden var gået tabt uden genstandene som medier/budbringere såvel i relation til arbejdslivet, til familie- og fritidslivet og til organisationslivet. Netop i relation til arbejderkulturen spiller genstandene en uhyre stor rolle, fordi denne kultur ikke er sprogligt, men materielt forankret. Dens udtryksmiddel er det materielle og ikke det talte eller skrevne. Det hænger sammen med hele læreprocessen i arbejdet. Arbejder bliver man ved at gå ind og påtage sig konkrete arbejdsopgaver, ikke ved at tilegne sig en abstrakt formuleret viden, men en konkret kropslig viden gennem udført arbejde. Selv om teknologiudviklingen har tvunget flere og flere arbejdere til også at indlære gennem sproget, er det fysiske kropslige, materielle stadigvæk en meget vigtig del af tilegnelsen.

Det materielle, tingenes verden, er arbejderkulturens vigtigste medie, vigtigste sprog, og på Arbejdermuseet er genstandene derfor af afgørende betydning, fordi de også sætter os i stand til at formulere den viden, vi indsamler om arbejderkulturen, og formidle den tilbage til vores publikum i netop det materielle sprog, det tingenes/genstandenes sprog, som de selv er fortrolige med. 
ANNETTE VASSTRÖM

60

NOTER

1. Niels Højlund, Højskoleforstander, TV-vært og debatør.

2. Christian Elling, dansk kunsthistoriker, professor.

Foredrag ved Museumshøjskolens museologiske forelæsninger, marts 1995 .

\section{SUMMARY}

Museum collecting and working-class culture

Collecting practice at the Workers' Museum in Copenhagen is described and discussed. First the author offers an argument for the field of collecting which the museum represents. The order of things as presented in a hierarchy determined by the market varies from another determined by the production of cultural heritage. However the two form a mutually reinforcing system. Beauty and uniqueness are highly valued in both hierarchies, and a museum looking for objects which do not belong to those categories represents a disturbance. But cultural history is largely produced by people whose conditions and experiences have long been overlooked. It has been possible to study working class history mainly in the library and archives of the Labour Movement. But it is argued that the worker's life experience can only be properly recorded through the methods of oral history and the collecting of everyday objects belonging to working life as well as home life and leisure. Such methods form the basis of the work in a museum of cultural history. A distinction is made regarding the preservation of industrial equipment, as the machines were owned by the industrialists not by the workers and should therefore be in the care of museums of technology. Examples of the collecting of the Workers' Museum are given in the form of objects from Copenhagen harbour and the donation to the museum of a wor- ker's living quarters in the city, an apartment left unchanged since 1915. The importance of the museum for the self-esteem of the workers is underlined and its support from all over Denmark is shown by two maps illustrating the localities where objects in the museum were used and the localities to which the donors belong.

Annette Vasström er mag. art. i europaisk etnologi. Museumsinspektor på Arbejdermuseet $i$ Kobenhavn siden 1986.

Adr: Arbejdermuseet, Romersgade 22,

DK-1362 Kobenhavn $K$. 